\title{
O CORPO FEMININO COMO FERRAMENTA DE PROTESTO \\ FEMINISTA E SUBVERSÃO AO MACHISMO NAS IMAGENS \\ DO MEME "BELA, RECATADA E DO LAR"
}

\author{
THE FEMALE BODY AS A TOOL OF FEMINIST PROTEST \\ AND SUBVERSION TO MACHISMO IN THE IMAGES \\ OF THE MEME "BELA, RECATADA E DO LAR" (BEAUTIFUL, MODEST AND HOUSEWIFE) \\ EL CUERPO FEMENINO COMO HERRAMIENTA DE PROTESTA FEMINISTA \\ Y DE SUBVERSIÓN AL MACHISMO EN LAS IMÁGENES \\ DEL MEME "BELA, RECATADA E DO LAR" (BELLA, RECATADA Y DEL HOGAR) \\ MARIA DAS GRAÇAS PINTO COELHO'
}

\section{EUGENIA BLANCO LÚGARO²}

\begin{abstract}
${ }^{1}$ Pós-doutorado em Comunicação pela Universidade Federal do Rio de Janeiro (UFRJ). Docente no Programa de Pós-graduação em Estudos da Mídia (PPGEM) da Universidade Federal do Rio Grande do Norte (UFRN) e coordenadora do Grupo de Estudos da Mídia (GEMINI), na mesma instituição. ORCID iD: https://orcid.org/0000-0002-6820-008X
\end{abstract}

${ }^{2}$ Mestranda do Programa de Pós-graduação em Estudos da Mídia (PPGEM) da Universidade Federal do Rio Grande do Norte (UFRN). ORCID iD: https://orcid.org/0000-0002-3096-3006

\section{RESUMO}

O meme "Bela, Recatada e do Lar" começou a circular após a revista Veja realizar uma reportagem em abril de 2016, que falava da então primeira dama Marcela Temer, trazendo estas palavras como elogios e atributos positivos. Em poucos dias ele se transformou em uma poderosa ferramenta midiática contra-hegemônica para fazer frente à narrativa criada pela revista. Neste artigo pretende-se analisar as construções simbólicas que permitiram a expansão desse meme. Para tanto, serão interpretados, a partir de uma análise de expressão simbólica, fundamentada na literatura sobre gênero, os memes imagéticos concentrados no Tumblr www.belarecatadaedolar.tumblr.com. Na análise, identifica-se que, os avanços tecnológicos e o feminismo em rede apresentam uma nova lógica no pensar e agir feminista, e os memes imagéticos analisados tornam-se ferramenta de disseminação mais rápida e em grande escala pelo seu alto grau de replicabilidade.

Palavras-chave: Feminismo. Subversão. Corpo. Mulher. 


\begin{abstract}
The meme "Bela, Recatada e do Lar" began to circulate after Veja magazine carried out a report on April 2016, about the first lady at that time, Marcela Temer, bringing these words as positives compliments and attributes. In few days it became a powerful counterhegemonic media tool to face the narrative created by the magazine. This article aims to analyze the symbolic constructions that allow the expansion of this meme. For this, we will interpret, through a symbolic expression analysis, based on the literature about gender, imagery memes concentrated on the Tumblr profile www.belarecatadaedolar.tumblr.com. In the analysis, it is identified that technological advances and network feminism present a new logic in feminist thinking and acting, and the imagery memes analyzed become a faster and large-scale dissemination tool for its high degree of replicability.
\end{abstract}

Keywords: Feminism. Subversion. Body. Woman.

\title{
RESUMEN
}

El meme "Bela, Recatada e do Lar" (Bella, recatada y del hogar) comenzó a circular al azar después de que la revista Veja publicó un reportaje el 18 de abril de 2016, en el que se hablaba de la entonces primera dama Marcela Temer, trayendo estas palabras como cumplidos y atributos positivos. En pocos días se convirtió en una poderosa herramienta mediática contrahegemónica para enfrentar la narrativa creada por la revista. En este artículo se pretende analizar las construcciones simbólicas que permitieron la expansión del meme. Con este fin, los memes imaginarios concentrados en Tumblr www.belarecatadaedolar.tumblr.com. En el análisis se identifica que los avances tecnológicos y el feminismo en red presentan una nueva lógica en el pensamiento y la actuación feminista, y los memes analizados se convierten en una herramienta de más rápida difusión y a gran escala debido a su alto grado de replicabilidad.

Palabras clave: Feminismo. Subversión. Cuerpo. Mujer.

\section{INTRODUÇÃO}

Ao longo da história social da cultura, o corpo da mulher é visto em diferentes abordagens categóricas, que atendem a necessidades socioculturais e econômicas, ou mesmo religiosas, que nem sempre estão de acordo com a subjetividade e desejos femininos. Wolf (1992) afirma que “desde a Revolução Industrial, as mulheres ocidentais da classe média vêm sendo controladas tanto por ideais e estereótipos quanto por restrições 
de ordem material.” (p. 18). Em sua teoria sobre o Mito da Beleza, afirma que a mulher é vista, julgada e socialmente condicionada a seguir um padrão estético e de comportamento androcêntrico para ser bem vista e aceita na sociedade. Esses padrões são justificados e postos como biológicos ao julgar a mulher feminina como um ser delicado, belo, puro e símbolo da reprodução e cuidados com o lar.

Entre outras pautas, o movimento feminista, surge com a preocupação de buscar e esclarecer o papel da mulher na sociedade, na década de 60. Desde então, lança no movimento social questões que antes se restringiam à esfera privada, mas também mecanismos para pensar direitos sociais de gênero, como a luta por plena igualdade de direitos, aceitação da identidade feminina e empoderamento social. Com a maximização desse movimento no ciberespaço ${ }^{1}$, o feminismo vem ganhando cada vez mais destaque e mais adeptas, graças aos fenômenos das redes sociais digitais que são uma das principais ferramentas de interação, compartilhamento e disseminação de informações e ideologias. Essas redes vêm sendo usadas como espaço de argumentação e questionamentos no que diz respeito ao machismo e patriarcado e servem como difusores de uma ideologia feminista chamada de Quarta Onda, que busca a igualdade de gêneros, dando voz aos diversos tipos de feminismos e tem a internet como balizadora.

Em abril de 2016, uma matéria intitulada; Marcela Temer: bela, recatada e "do lar",2, feita pela jornalista Juliana Linhares na Revista Veja, falava sobre a primeira-dama, esposa do então presidente Michel Temer, enaltecendo-a e colocando-a como "mulher ideal" por estar inserida dentro do cenário de espaço doméstico privado, como mãe e esposa, apropriando-se dos adjetivos "bela, recatada e do lar" na manchete. Essa visão do papel da mulher remete às narrativas machistas e patriarcais de "mulher ideal" e foi

\footnotetext{
${ }^{1}$ Consideramos a teoria de Lemos $(2008$, p. 128) que define o ciberespaço como "[...] um não-lugar, uma utopia onde devemos repensar a significação sensorial de nossa civilização baseada em informações digitais, coletivas e imediatas. Ele é um espaço imaginário, um enorme hipertexto planetário". Ou seja, um novo meio de comunicação que surge através da tecnologia dos computadores e da interconexão.

2 Disponível em: https://veja.abril.com.br/brasil/marcela-temer-bela-recatada-e-do-lar/ - Acesso em: $22 / 11 / 2018$
} 


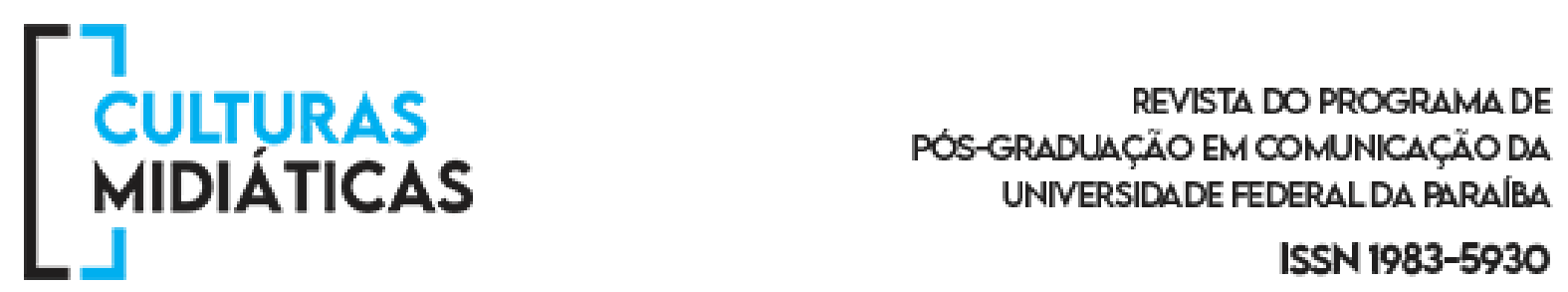

amplamente criticada por muitos internautas que se apropriaram dessa tríade de adjetivos para criar a hashtag memetizada \#BelaRecatadaedoLar com uma reconstrução da narrativa usando a ironia para retrucar a posição da revista.

O trabalho tem como objetivo identificar, qualificar e entender como ocorre a apropriação dos memes imagéticos no movimento feminista, que trazem o corpo feminino em destaque, que é usado no meio digital, de forma semipública, como ferramenta da luta feminista e na construção de discursos do movimento.

Esta pesquisa apoia-se em estudos sobre memética (DAWKINS, 1976; SHIFMAN, 2013, 2014), além de estudos feministas, sobre gênero e sobre corpo (BUTLER, 1986; (WOLF, 1992; GOMES; SORJ, 2014) para entender a perspectiva feminina da Revista Veja e a perspectiva feminista sob a mulher, trazendo o uso do corpo como protesto. Essas duas teorias unem-se para entender como e porque nasce um meme feminista que usa o corpo da mulher para subversão da visão feminina colocada na reportagem da Revista Veja.

\section{A IMAGEM DA MULHER NA REPORTAGEM DA REVISTA VEJA}

Ao adjetivar Marcela Temer como "bela, recatada e do lar" identificando tais aspectos como qualidades a serem exaltadas em uma mulher, a revista Veja indica uma imposição de gênero e posiciona a visão feminina biológica e relativa ao espaço privado de dona de casa, mãe e reprodutora. Esta tríade de adjetivos nos leva a construção de uma imagem da mulher estereotipada, pertencente ao imaginário masculino, na qual a beleza física, a pureza, a inocência e a dedicação exclusiva ao lar são de extrema importância para que seja considerada "perfeita". Isto é defendido na reportagem em alguns trechos, como estes a seguir: “A quase primeira-dama, 43 anos mais jovem que o marido, aparece pouco, gosta de vestidos na altura dos joelhos e sonha em ter mais um filho com o vice". 3

3 Disponível em: https://veja.abril.com.br/brasil/marcela-temer-bela-recatada-e-do-lar/ - Acesso em: $22 / 11 / 2018$ 
Nessa segregação de espaço para homem e mulher, o homem ocupa majoritariamente o espaço público com a condição de trabalho e superioridade, enquanto a mulher ocupa o espaço privado do lar e da reprodução familiar. Sendo tal separação fruto da influência que dicotomiza público e doméstico, masculino e feminino, o que acontece em decorrência do lugar que a mulher ocupa no campo da reprodução, confundindo a intimidade como espaço feminino (ALMEIDA, 1997).

O trabalho doméstico (fazer e determinar compras, cuidar e dirigir a educação dos filhos, responsabilizar-se pela cozinha, limpeza da casa, roupas, organização do espaço doméstico etc) é basicamente uma atividade reprodutiva porque através dela a mulher cria valores de uso com os quais trabalhadores e herdeiros sobrevivem rotineiramente (...) O trabalho doméstico está no cerne da opressão feminina e enquanto o casamento incluí-lo como um mecanismo, através do qual serviços são prestados gratuitamente e crianças geradas e criadas, tendo uma mulher como responsável, a opressão dessa, com ou sem propriedades, com ou sem alternativa de um trabalho assalariado, parece inevitável. (JUNHO PENA, 1981, p.73).

Tal dicotomia entre a mulher no espaço público e privado tem gerado grandes discussões feministas porque impõe uma ideologia patriarcal superior baseada nessas diferenças biológicas que desvalorizam situações em que mulheres atuam e detém de poder e autoridade tanto quanto os homens. Criou-se uma falsa ideia de que mulheres são inferiores por natureza, por possuírem um útero, que as faz serem naturalmente dedicadas à reprodução, ao lar, ao ambiente privado, sem considerar a vontade da mulher de ser mãe ou dona de casa. Coloca-a nesse local como uma "conformação biológica” (TOLEDO, 2001, p. 23).

Em outros fragmentos da reportagem da revista, podem-se enxergar também os atributos físicos considerados "belos" e a discrição de Marcela Temer quanto a forma de se vestir como pontos relevantes de uma mulher.

A imagem de Marcela é tida seguindo padrões estéticos e características da mulher que foram critérios femininos durante muito tempo em sociedades ocidentais, seguindo um 
senso comum em que a beleza estética e uma posição de pureza seriam uns dos atributos mais importantes e reverenciados em uma mulher. Estes padrões estão inseridos no que Wolf (1992) chama de "mito da beleza", que é a busca por critérios estéticos e comportamentais femininos impostos por uma visão masculina hegemônica que tendem a oprimir as mulheres.

A ascensão do mito da beleza foi somente uma dentre as várias ficções sociais incipientes que se disfarçavam como componentes naturais da esfera feminina para melhor encerrar as mulheres que ali estavam. Surgiram simultaneamente outras ficções: uma visão da infância que exigia permanente supervisão materna; uma concepção da biologia feminina que forçava as mulheres da classe média a fazer o papel de histéricas e hipocondríacas; uma convicção de que as mulheres respeitáveis não tinham sensibilidade sexual; e uma definição do trabalho feminino que ocupava as mulheres com tarefas repetitivas, demoradas e trabalhosas como, por exemplo, o bordado e a renda feita à mão. (WOLF, 1992, p.18 e 19).

Essa desvalorização da mulher no espaço público e a supervalorização da mulher no âmbito privado como sendo "do lar", Fraser (2009) denomina de desvalorização do trabalho não-assalariado, como consequência de uma sociedade de cultura capitalista na qual o cidadão ideal é masculino, trabalhador, branco, chefe e homem de família. Dessa forma foi-se "institucionalizando compreensões androcêntricas de família e trabalho, naturalizou injustiças de gênero e as removeu da contestação política” (FRASER, 2009, p. $38)$.

Uma das principais lutas feministas, foi - e ainda é - pela emancipação e valorização no espaço público com direitos igualitários aos homens, e estes motivos foram os gatilhos principais para a indignação e retrucamento da notícia da revista Veja que coloca a "mulher perfeita" como sendo exclusivamente pertencente ao espaço privado.

\section{O “SER” MULHER E AS IMPOSIÇÕES DE GÊNERO}




\section{CULTURAS MIDIÁTICAS}

A frase de Beauvoir que diz que não se nasce mulher, mas torna-se (grifo nosso), nos faz entender que a imagem caracterizada como feminina não é algo biológico, mas sim algo que acontece por uma série de atos e normas cultural e socialmente impostas. O gênero, desta forma, faz parte de um jogo de diferenciações e referências nas quais as mulheres são performaticamente colocadas como seres do âmbito privado, frágeis e reprodutoras, por exemplo.

Para que haja a libertação de padrões estéticos e comportamentais é necessário complexificar o debate de gênero e desconstruir a dicotomização dos sujeitos em feminino/masculino e homem/mulher heteronormativos, que desconsideram qualquer outra forma de ser. Trazer os termos "homem" e "mulher" carregados de rótulos culturais e sociais, imutáveis e justificados biologicamente criam definições perigosas e reproduzidas, como: o homem sendo um ser forte, dominador e insensível e a mulher como um ser delicado, fraco e submisso. Essas amarras sociais e culturais condenam os seres de cada gênero a serem apresentados, comparados e caracterizados de forma simplista e problemática ao descaracterizar as individualidades e variações de cada ser. Beauvoir aponta essa padronização como forma de reconhecer-se no todo quando diz:

Não é enquanto corpo, é enquanto corpos submetidos a tabus, a leis, que o sujeito toma consciência de si mesmo e se realiza: é em nome de certos valores que ele se valoriza. E, diga-se mais uma vez, não é a fisiologia que pode criar valores. Os dados biológicos revestem os que o existente lhe confere. (2009; p. 78).

Ao falar dessas imposições de gênero, Butler (2008) fala de performatividade, que é a atividade de reproduzir atos corporais e de comportamento pré-estabelecidos e fixados em uma cultura de forma regulatória e repetitiva que implica na uniformidade de um comportamento considerado coerente e aceitável culturalmente para homens ou mulheres. É importante ressaltar que a autora não traz o gênero performativo como uma atividade derivada dos indivíduos, mas sim que o mundo, os outros, as instituições performam o 


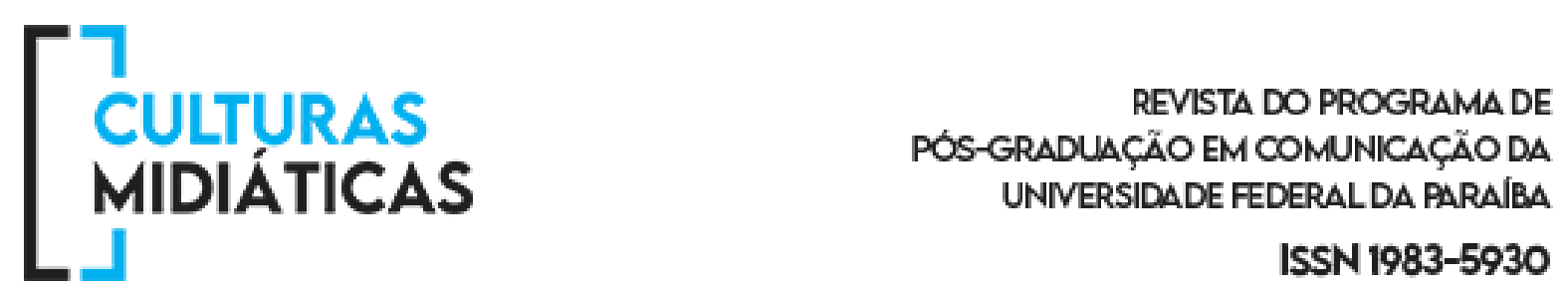

corpo. Essas normas podem ser consideradas limitantes e excludentes já que não seria possível considerar um sujeito fora desses padrões, "se a existência é sempre marcada pelo gênero, então desviar-se do gênero estabelecido é em algum sentido colocar a própria existência de alguém em questão" (BUTLER, 1986, p.42).

Desta forma, é essencial compreender que ser mulher é, não uma consequência direta da biologia ou anatomia humana, nem de processos culturais imutáveis, mas de processos contínuos de compreensão e reprodução de valores, comportamentos e ideologias impressas na sociedade como um todo. Por isso, atos como recusa da maternidade, trabalho braçal feminino, posição de superioridade na sociedade e a não atuação como um ser frágil, geram estranhamento e descaracterizam as mulheres como seres femininos por rumarem contra os modos de agir pré-estabelecidos. Ou seja, ir contra a binaridade sexual "homem X mulher", contra os adjetivos "bela, recatada e do lar", é ir contra o que culturalmente é considerado na sociedade patriarcal como "ser mulher". E é exatamente isso que buscou-se fazer nas imagens do Tumblr analisado: descaracterizar a visão androcêntrica da mulher e seu local como sendo no espaço privado do lar.

\section{O MEME POLÍTICO “BELA, RECATADA E DO LAR” E O USO DO CORPO FEMININO COMO FERRAMENTA DE PROTESTO}

Antes de trazer a problematização, é importante percorrer pela a teoria da memetização para entender como ela se aplica ao presente trabalho. A terminologia do meme foi inicialmente usada por Dawkins (1970), ao abordar a similaridade do gene biológico, para explicar um fenômeno cultural, ambos tendo como característica predominante a imitação. O que ele chama de meme é esse elemento replicador que passaria por uma seleção natural e seria repassado de indivíduo para indivíduo, são eles: ideias, slogans, moda, bordões, entre outros.

Esse conceito foi flexibilizado e trazido para o âmbito cibernético, criando o termo memes da internet, que é o espalhamento on-line de forma contínua de frases, imagens, 
boatos e/ou piadas que são reapropriadas ao contexto dos indivíduos, sendo replicados em grande escala. Inocêncio (2014) caracteriza esse fenômeno dizendo que "um atributo central dos memes de internet é a produção de diferentes versões a partir de um objeto inicial, versões essas que são criadas pelos usuários e articuladas como paródias, remixes ou mashups" (p.355). Apesar de fundamentados de forma diferente, o termo de meme de Dawkins (1976) e os memes da internet tem sua principal característica em comum: são replicadores e replicados.

Ao falar do meme "bela, recatada e do lar”, precisamos ir além das características básicas desse fenômeno, que são sua estética amadora e seu viés essencialmente cômico, os memes também podem ser políticos e o trazido neste trabalho se enquadra neste sentido. Dentro dessa segmentação, está o que Shifman (2013) os denomina de memes de ação popular. Que, como o nome antecipa, caracterizam-se por uma ação coletiva popular. Quando um grupo segue um padrão de comportamento, em prol do mesmo objetivo. Chagas (2016) aponta que esse tipo de meme desenrola-se a partir de quatro tipos de ações:

(a) ações coletivas operando através de redes curadas por organizações, de (b) ações conectivas híbridas operando através de redes catalisadas por organizações e movimentos sociais, de (c) ações conectivas stricto sensu, operando a partir de redes auto-organizadas e auto-gestadas, e finalmente de (d) ações conectivas de engajamento relativo, cujo principal traço é a dificuldade em se identificar efetivo engajamento político na ação empreendida. (CHAGAS, 2016).

O meme em questão, nesse contexto, encaixa-se como um meme de ações conectadas heterogêneas, já que começou com uma hashtag, espalhando-se para diversas redes sociais, transformando-se em um meme imagético e sendo apropriado pelo movimento feminista, com muitas das imagens usando o corpo como ferramenta para ir contra a visão da mulher pela reportagem da Revista Veja. 
O meme estudado, traz dois formatos atrelados a si: o formato hashtag $^{4}$ e o formato imagético, podendo ambos aparecer juntos, ou não. Após a reportagem da Veja citada, criou-se a hashtag \#BelaRecatadaEDoLar, que nasceu no Twitter e se espalhou por outras redes sociais como Facebook e Instagram, com milhares de menções. Além disso, foram criados blogs, microblogs e páginas em redes sociais com a temática da matéria usando e transformou-se em um meme imagético, já que na sua composição estavam uma imagem, geralmente de mulheres em seus ambientes privados, mostrando suas experiências e corpos, atrelados à tríade de adjetivos, que as vezes aparece em formato de hashtag, às vezes não. Ele foi sendo replicado por mulheres de todo o país com viés feminista para questionar e reivindicar a imagem feminina da reportagem da Revista Veja.

Entre os conteúdos criados, foi feito um Tumblr, seu título é a mesma tríade de adjetivos usada na manchete: "Bela, Recatada e do Lar" e teve por objetivo desmistificar a imagem feminina imposta na matéria recebendo fotos enviadas espontaneamente por mulheres que buscavam mostrar outras visões femininas e ironizar a apresentada pela Veja. A página pode ser considerada feminista e a favor da diversidade da mulher e isso é explícito no texto de apresentação: "Tudo bem ser bela, recatada e do lar. Tudo bem ser o completo oposto disso. Porque ao contrário do que a Veja gostaria de impor, as mulheres vão ser o que elas bem entenderem!"’ e logo abaixo seguem fotos variadas nas quais mulheres usam suas imagens e seus corpos em situações de deboche, desregramento ou caracterizadas como não aceitas socialmente para mulheres, ironizando o discurso inicial, imagens como de uma mulher bebendo bebida alcóolica, mostrando o corpo, mostrando-se sexualmente livres, fazendo trabalhos tradicionalmente direcionados aos homens, entre outros.

\footnotetext{
${ }^{4}$ A hashtag surgiu na internet e é uma expressão que inicia com o caractere \# (jogo da velha), são usados para definir uma temática em pauta e com esse símbolo antes da expressão podem ser mais fácil encontrados dentro das redes sociais.

${ }^{5}$ Disponível em: www.belarecatadaedolar.tumblr.com <Acesso: 22/11/2018>.
} 
O corpo feminino é utilizado como ferramenta comunicativa há muito tempo nas artes. O nu, o erotismo, o grotesco, entre outros, foram e são usados em esculturas, pinturas e outras manifestações artísticas que buscam expressar-se através dele. Para Carlson (2009) a utilização do corpo feminino como ferramenta comunicacional e política não é obra do acaso, faz-se uso dele para tentar desmistificar a narrativa social patriarcal de mulher como ser objetificado.

A utilização do corpo na performance pode, assim, fornecer uma alternativa para a própria ordem simbólica da linguagem que, segundo muitas teóricas feministas afirmam, não fornece abertura para a representação da mulher (CARLSON, 2009, p. 191-192).

Como veremos na análise a seguir, os memes criados no Tumblr "bela, recatada e do lar" utilizaram o corpo como principal ferramenta de oposição à imagem da mulher feminina apresentada pela Revista Veja. O corpo foi usado como principal ferramenta subversiva ironizando de forma performativa a tríade de adjetivos. Esses memes imagéticos criaram "imagens de um corpo feminino que funciona como contra discurso, a partir de uma visibilidade máxima, uma estética do escândalo, que usa a sedução, o erotismo, o humor, a inversão, o choque e o consumo para desconstruir tabus, inventar novos lugares de fala.” (BENTES, 2017, p. 97). 

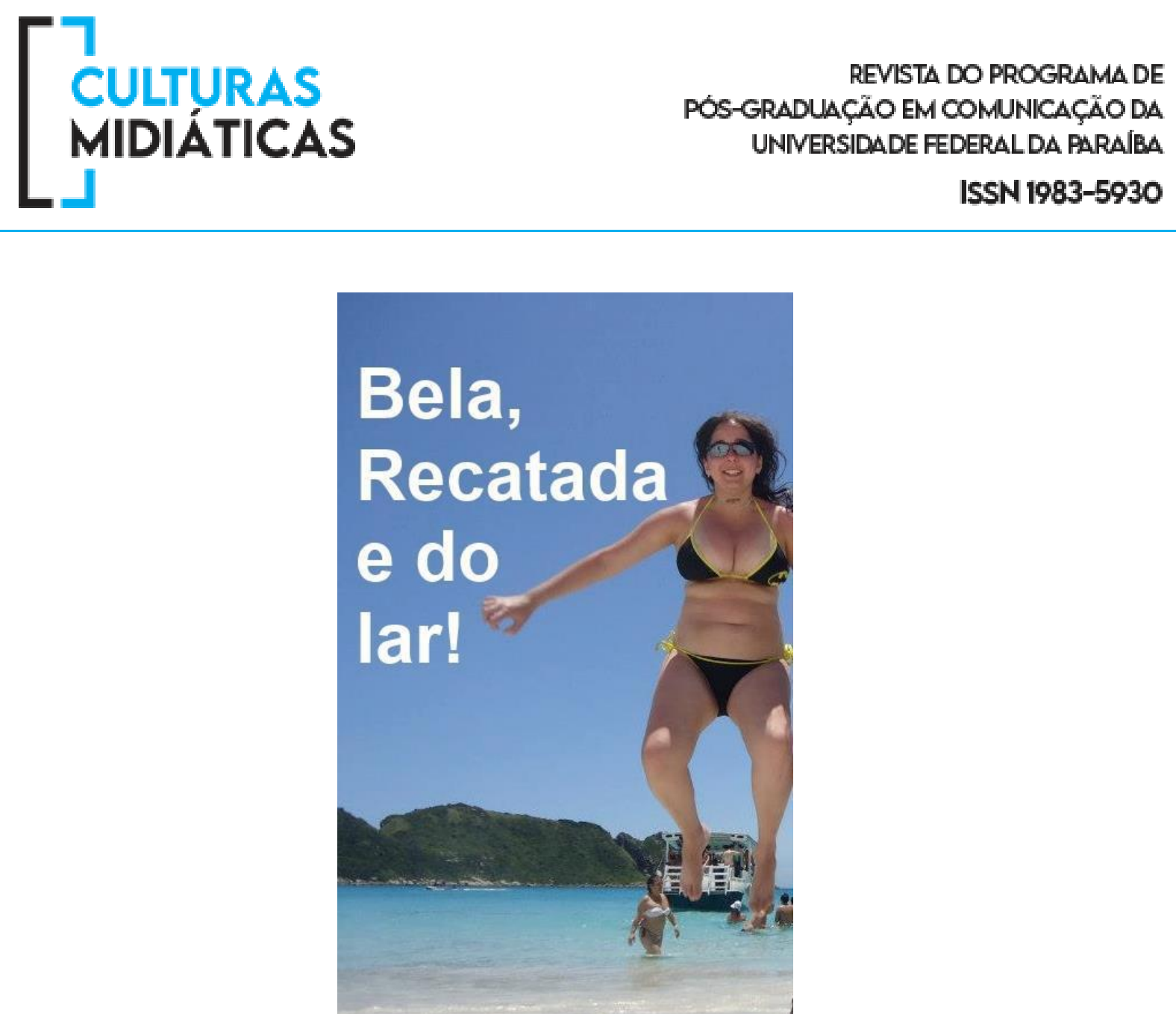

Figura 1 - Mulher "bela".

Fonte: Tumblr "Bela, Recatada e do Lar"

Ao falar sobre o uso do corpo como ato político, Wolff (2011) cita Bakhtin e a existência de um corpo clássico - aquele que não tem orifícios e não desempenha nenhuma função corporal básica, e o corpo grotesco, aquele com orifícios, protuberâncias e genitálias. Os corpos subversivos do meme "bela, recatada e do lar" podem ser categorizados como corpos grotescos, já que buscam atuar de forma racional, ocasionando uma discussão política ao tornar visíveis os traços femininos suprimidos na matéria da Veja, que são um reflexo das características femininas anuladas por uma visão masculina hegemônica da mulher.

$\mathrm{Na}$ (Figura 1) podemos ver uma mulher de biquíni pulando, nela é possível ver dobras de gorduras na barriga e peitos avantajados. Tais características fogem aos padrões 
instaurados de beleza que incitam a mulher a ser magra, esbelta, alta, de traços finos e delicados.

A reportagem sobre Marcela Temer evidência tais características de beleza da então primeira-dama em trechos como este: "Bacharel em direito sem nunca ter exercido a profissão, Marcela comporta em seu curriculum vitae um curto período de trabalho como recepcionista e dois concursos de miss no interior de São Paulo (representando Campinas e Paulínia, esta sua cidade natal). Em ambos, ficou em segundo lugar. Marcela é uma viceprimeira-dama do lar.".

A imagem da beleza feminina apontada no trecho acima é representada por uma visão masculina, e se reflete em uma busca incessante por parte das mulheres por um padrão imposto por essa visão androcêntrica. Essa procura por uma estética harmônica e padronizada gerou estereótipos femininos a serem seguidos para poder ter aceitação social. A teoria do Mito da Beleza de Wolf (1992) ratifica tal ditadura da beleza ao afirmar que:

Encarnar a beleza é uma obrigação para as mulheres, não para os homens, situação esta necessária e natural por ser biológica, sexual e evolutiva. Os homens fortes lutam pelas mulheres belas, e as mulheres belas têm maior sucesso na reprodução. A beleza da mulher tem relação com sua fertilidade; e, como esse sistema se baseia na seleção sexual, ele é inevitável e imutável. (p. 15).

A partir da terceira onda feminista, iniciada nos anos 80, enxergou-se a pluralidade por trás das mulheres, entendendo as diferenças de raça, classe e padrões, por isso, quebrar a busca por uma beleza padrão e desumana para todas as mulheres faz parte também do movimento. Passou-se a considerar as mulheres através de sua pluralidade do ser e do ver, quebrando padrões “de revista” e expondo o corpo como ele é de verdade.

Retratar em massa a mulher moderna como uma "beldade" é uma contradição. Enquanto a mulher moderna está crescendo, mudando e exprimindo sua individualidade, como o próprio mito sustenta, a "beleza" é por definição inerte, atemporal e genérica. $O$ fato de essa alucinação ser necessária e deliberada fica evidente na forma pela qual a "beleza" 


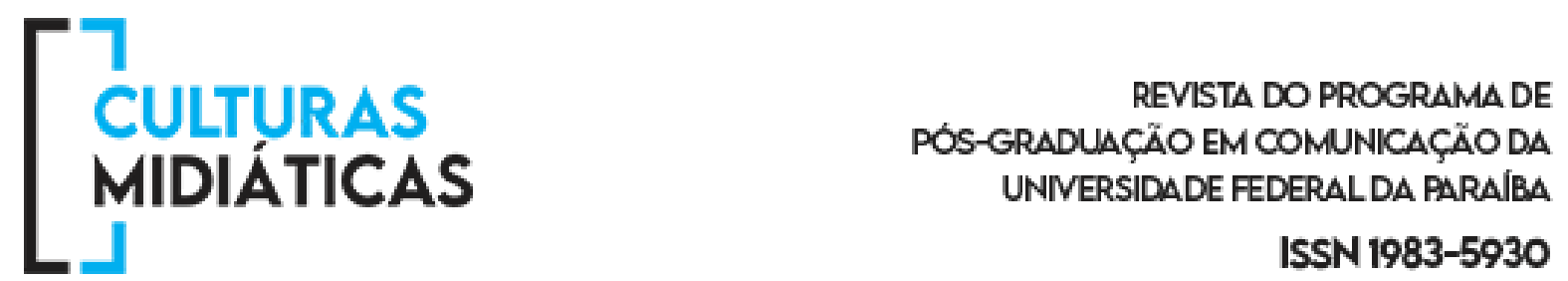

contradiz de forma tão direta a verdadeira situação das mulheres. (WOLF, 1992, p. 21).

Ao mostrar uma mulher que não segue os padrões estéticos de beleza que definem uma mulher como bonita, a (Figura 1) cria um ruído que desnaturaliza a beleza como sendo aquela composta por apenas um tipo de corpo exposto, o corpo clássico que não tem orifícios e não desempenha nenhuma função corporal básica, e também aquele liso, sem gorduras ou celulites, por exemplo.

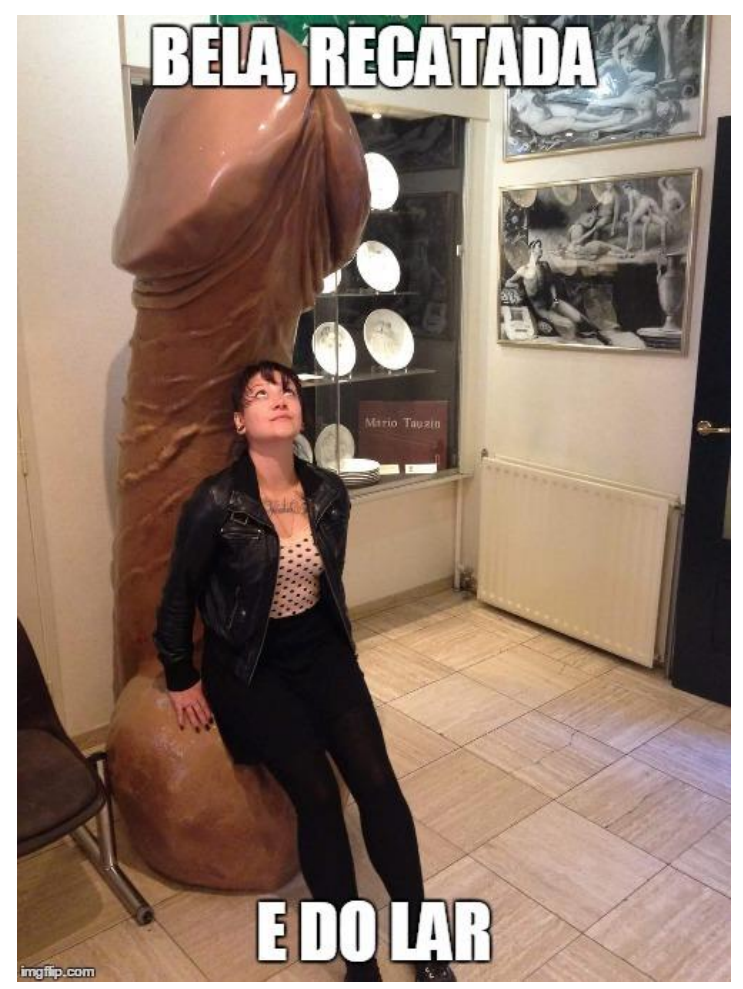

Figura 2 - Mulher "recatada". Fonte: Tumblr "Bela, Recatada e do Lar"

A Figura 2, colocou uma mulher com uma escultura de um pênis gigante atrás. Tal imagem quebra o padrão de que mulher não deve falar ou estar associada à sexualidade própria, ou referir-se a qualquer elemento que remeta à sexualidade masculina. Mais uma 


\section{CULTURAS \\ MIDIATICAS}

REVISTA DO PROGRAMADE

PÓS-GRADUAÇÃO EM COMUNICAÇÃO DA

UNIVERSIDADE FEDERAL DA PARAIBAA

ISSN 1983-5930

vez desvalidando a reportagem da Veja que coloca Marcela Temer como uma mulher recatada, considerando uma característica louvável dela não expor o corpo, como vemos no trecho a seguir: "Marcela sempre chamou atenção pela beleza, mas sempre foi recatada", diz sua irmã mais nova, Fernanda Tedeschi. "Ela gosta de vestidos até os joelhos e cores claras", conta a estilista Martha Medeiros."

A segunda onda feminista, a partir dos anos 60, tinha como principal característica defender e reivindicar peculiaridades femininas como sexualidade, corpo feminino e mercado de trabalho. O feminismo desse momento "deu prioridade às lutas pelo direito ao corpo, ao prazer, e contra o patriarcado - entendido como o poder dos homens na subordinação das mulheres" (PEDRO, 2005, p. 79). Esta luta segue ainda até hoje e, por isso, tais afirmações da reportagem que vão contra estas reivindicações geraram insatisfação das mulheres que lutam pela liberdade dos seus corpos e dos seus desejos como seres sexuais.

A imagem e comportamento da mulher sempre estiveram associados a uma natureza religiosa de pureza e pudor que reprime a sua sexualidade. As crenças religiosas nunca tiveram influências reais sobre a masculinidade ou sexualidade dos homens, mas sempre tratou as mulheres como seres sexualmente inexistentes, considerando o sexo como ato impuro ou pecaminoso. Tais comportamentos podem ser observados, por exemplo, na bíblia, em Maria, mãe de Jesus, a qual é tida como santa e "livre do pecado" por ter sido mãe virgem.

Essa influência religiosa deu-se na sociedade desde os primórdios da humanidade e pode ser vista até hoje. O desejo sexual é considerado um papel apenas masculino, reprimindo-se veemente as mulheres que o expressem, a mulher e sua imagem resumem-se a estar a serviço do homem, seja pelo seu próprio pudor como objeto de beleza e do lar, ou como objeto sexual, promovendo o desejo e poder masculino. Dessa forma, criou-se uma convicção de que mulheres respeitáveis são recatadas e não têm sensibilidade sexual. Sobre isso WOLF (1992) diz que: 
Tanto os homens quanto as mulheres tendem a erotizar somente o corpo da mulher e o desejo do homem. Isso resulta numa sensibilidade exagerada das mulheres quanto ao desejo masculino para sua própria excitação, enquanto os homens são exageradamente insensíveis ao desejo feminino para a deles. (p. 210).

O pênis é o principal símbolo de prazer feminino e sexualidade masculina. Ao ser exposto e colocado ao lado de uma mulher, simboliza a subversão do termo "recatada" e da mulher não sexualizada e passiva de desejos, descaracterizando a imagem de pureza relacionada a não abordagem da sexualidade feminina.

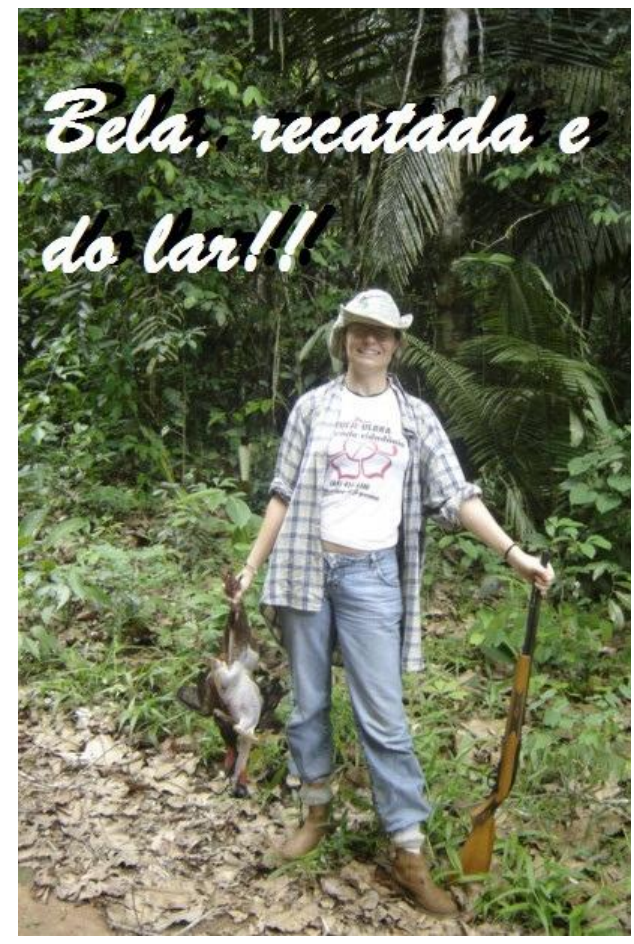

Figura 3 - Mulher "do lar".

Fonte: Tumblr "Bela, Recatada e do Lar"

A reportagem da Veja também traz a visão feminina do espaço privado do lar como uma característica essencial da "mulher perfeita", colocada em afirmações, como: “[...] Marcela é uma vice-primeira-dama do lar. Seus dias consistem em levar e trazer 
Michelzinho da escola, cuidar da casa, em São Paulo e um pouco dela mesma também (nas últimas três semanas, foi duas vezes à dermatologista tratar da pele)".

Esta visão patriarcal do papel da mulher na sociedade foi um dos primeiros e principais pontos de subordinação da mulher ao homem e que vem sendo combatida desde os primórdios das lutas feministas, no século XIX, com a primeira onda do feminismo, na qual as mulheres inglesas questionaram a falta de direito ao voto. O movimento sufragista representação principal dessa primeira etapa foi a busca da validação das mulheres como cidadãs.

Podem-se considerar como principais causas (históricas, políticas e sociais) desencadeadoras do feminismo, a revolução Industrial, num primeiro momento, e as duas grandes guerras num segundo momento. As principais reivindicações desta vaga foram essencialmente pelo direito ao voto, pelo qual o movimento sufragista se caracterizou, e pelo acesso ao estatuto de 'sujeito jurídico'. (NOGUEIRA, 2015).

A dicotomia entre a mulher no espaço público e privado tem gerado grandes discussões feministas por impor uma ideologia patriarcal superior baseada em diferenças biológicas entre homens e mulheres que desvaloriza a mulher em posições e situações nas quais elas detêm de autoridade, conhecimento e/ou poder tanto quanto os homens. "A capacidade que a mulher tem de procriar passou a ser vista como sinal de fraqueza, de debilidade, servindo a um aumento da exploração do trabalho feminino e do controle sobre a reprodução.” (TOLEDO, 2008, p. 29)

A reportagem da Veja reafirma tal dicotomia, colocando o espaço privado como o lugar certo para a mulher. Essa ratificação da visão machista da mulher e da sua nãoparticipação na vida pública foi um dos grandes alvos dos memes gerados com a tríade "bela, recatada e do lar”. Para ilustrar, colocou-se a (Figura 3), que mostra uma mulher em situação de prioridade masculina: a função de caçar e manusear armas. Ao trazer uma mulher com uma presa caçada em uma mão, uma espingarda em outra e ainda com vestimentas de um padrão masculino (calça folgada, camiseta e camisa por cima), esse 
meme busca abalar a imagem de mulher "do lar", dedicada ao espaço privado de cuidado da casa e com os filhos, além de sutilmente, também subverter a mulher bela e feminina. $\mathrm{O}$ uso, por uma mulher, de ícones e representações destinadas aos homens busca defender a quebra de padrão pelos quais se dá o senso comum machista de associação do feminino à fragilidade e ao lar.

A repressão do corpo feminino na Cultura Ocidental acontece através de práticas, ideologias e discursos que o dominam e definem. Por isso, usá-lo como forma de contrariar e desordenar essa posição pode desafiar a ordem estabelecida e mantê-lo em lugar privilegiado para gerar subversão e intervenção política.

É preciso considerar ainda que usar o corpo subversivo para desconstruir um pensamento machista pode ser perigoso, já que esse olhar masculino ainda é dominante e culturalmente disseminado e tal posição pode passar a imagem inversa, mantendo o pensamento que está sendo posto em cheque.

A lição (pelo menos uma delas) é que é problemático usar o corpo feminino para fins feministas. Os seus significados pré-existentes, como objecto sexual, como objecto do olhar masculino, podem sempre prevalecer e reapropriar -se do corpo, apesar das intenções da própria mulher. (WOLFF, 2011, p. 102 e 103).

A utilização do corpo como uma ferramenta de comunicação, seja na arte, nas ruas, ou através de memes na internet, indica um corpo crítico transformado em corpo-político, como Barbara Kruger ${ }^{6}$ diz em seus trabalhos, o "corpo como campo de batalha": aquele que busca representatividade na sua diversidade de ser e liberdade na sua forma de agir. $\mathrm{O}$ corpo torna-se um corpo-bandeira (GOMES; SORJ, 2014), aquele usado como ferramenta política, "pelo artifício da provocação, o corpo é usado para questionar as normas de gênero, em especial as regras de apresentação do corpo feminino no espaço público. Ao

\footnotetext{
${ }^{6}$ Artista norte-americana Barbara Kruger (1945-), suas composições em maioria apropriam-se de imagens fotográficas (geralmente retiradas de comerciais de revistas e jornais) em preto e branco e da sobreposição de textos de linguagem simples e direta, mas cuja mensagem subverte o sentido inicial da imagem.
} 
mesmo tempo, o corpo é um artefato no qual cada participante procura expressar alguma mensagem que o particulariza." (p. 437). É o corpo privado tornando-se artifício público, mas acima de tudo, tornando-se artifício político pela luta das mulheres.

\section{CONSIDERAÇÕES FINAIS}

Com a análise de expressão simbólica de algumas das imagens do meme "bela, recatada e do lar" pode-se observar que o movimento feminista - através da quarta onda, o ciberfeminismo, vem ganhando força dentro das redes sociais buscando refutar visões machistas impostas por grandes meios de comunicação, como foi o caso da Revista Veja em sua reportagem sobre Marcela Temer.

Para descaracterizar a visão da mulher por uma ótica machista, esse meme fez uso do corpo como campo de batalha, um corpo-bandeira, usando-o de forma a subverter a ordem e desnaturalizar os padrões físicos e de comportamento da sociedade patriarcal. Wolff (2011) defende o uso do corpo como política transgressiva ao falar que "o que penso podermos de facto afirmar com segurança é que a própria aparência dessas imagens transgressivas e respectivas práticas e ideias são importantes na medida em que tornam visível o que estava reprimido.” (p. 109, grifo nosso). E enxergar imagens e atitudes estereotipadas da mulher que, na maioria das vezes, não condizem com a realidade feminina, incitou as mulheres a substituir tal visão machista disseminada pela Revista Veja e ter um corpo autônomo e independente, um corpo político que busca lutar pela igualdade de gênero e pelo reconhecimento das diferenças.

As imagens estudadas fazem uso, através de imagens, da subversão dos estereótipos como recurso para gerar reflexões e indagações sociais e culturalmente importantes para gerar mobilização e conscientização sobre pautas importantes dentro do feminismo e da imagem da mulher na sociedade. A utilização do corpo como forma de protesto é a busca das mulheres por ter controle sobre seu próprio eu, sobre a sua imagem e sobre como ela quer ser passada à sociedade, é a busca por aceitação do ser como se é e pela quebra de padrões. O corpo pessoal transforma-se em um corpo político e de luta. Usar o corpo 


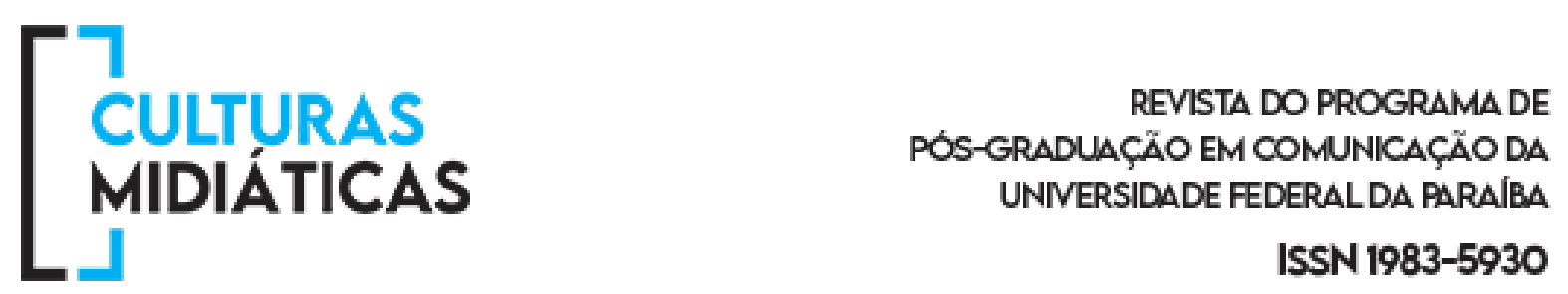

performático como protesto faz parte do processo de transgressão rumo à igualdade de gênero.

Através do meme "bela, recatada e do lar" o corpo ganha um novo olhar sobre si mesmo, um olhar ativo que busca sua própria forma de enxergar-se mulher. Traz um corpo que deixa de ser posse de uma coletividade ou de um padrão comum e torna-se propriedade única da própria mulher, usando da ironia, do riso e da imagem para mostrar uma ótica feminina real. Um olhar político. Um olhar subversivo.

\section{REFERÊNCIAS}

ALMEIDA, S.S. Violência de gênero: público X privado. Tese (Doutorado em Ciências Sociais) - Pontifícia Universidade Católica de São Paulo. São Paulo, 1997.

BEAUVOIR, Simone de. O Segundo Sexo I. Revisão de Carlos Pinheiro. Lisboa: Quetzal Editores, 2009.

BENTES, Ivana. Biopolítica feminista e estéticas subversivas. Matrizes, São Paulo, v. 11, n. 2, p. 93-109, 2017.

BUTLER, Judith. El gênero em disputa. El feminismo y la subversión de la identidad.

Traducción Ma. Antonia Muñoz. Barcelona: Paidós, 2008.

BUTLER, Judith."Sex and Gender in Beauvoir's Second Sex". In: Yale French Studies, Simone de Beauvoir: Witness to a Century, no 72, Winter 1986.

CARLSON, Marvin. Performance: uma introdução crítica. Belo Horizonte: UFMG, 2009.

CHAGAS, V. "Não tenho nada a ver com isso": cultura política, humor e intertextualidade nos memes das Eleições 2014. In: ENCONTRO ANUAL DA COMPÓS, 25., 2016, Goiânia. Anais... Goiânia: UFG, 2016.

DAWKINS, Richard. O gene egoísta. Belo Horizonte: Ed. Itatiaia, 1976.

FRASER, Nancy. Feminismo, capitalismo e a astúcia da história. Mediações, Londrina, v. 14, n.2, pp. 11-33, Jul./Dez. 2009.

GOMES, Carla; SORJ, Bila. Corpo, geração e identidade: a Marcha das Vadias no Brasil. 


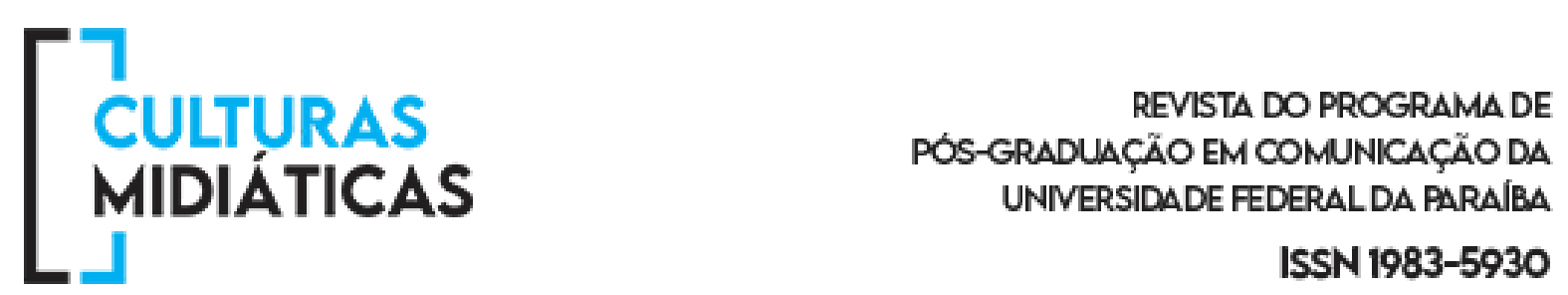

Revista Sociedade e Estado, Brasília, v. 29, n. 2, p. 433-447, Maio-Agosto/ 2014. Disponível http://www.scielo.br/scielo.php?script=sci_arttext\&pid=S010269922014000200007 Acesso em: 25 jul. 2020.

INOCÊNCIO, Luana; LOPES, Camila. The Zuera Never Ends: interação, compartilhamento e potências virais das imagens meméticas em comentários no Facebook. In: Anais do XVI Congresso Intercom Regional, 2014. Disponível em: <http://goo.gl/2oNVsX>. Acesso em: 23 jan. 2019.

JUNHO PENA, Maria Valéria. Mulheres e trabalhadoras: presença feminina na constituição do sistema fabril. Rio de Janeiro: Paz e Terra, 1981.

LEMOS, André. Cibercultura: tecnologia e vida social na cultura contemporânea. 4.ed. Porto Alegre: Sulina, 2008.

LINHARES, Juliana. Marcela Temer: bela, recatada e “do lar". Veja.com. 18/04/2016. Disponível em: . Acesso em: 19 de abril de 2016.

NOGUEIRA, Conceição. Feminismo e discurso de gênero na psicologia social. Revista da Associação Brasileira de Psicologia Social, 2001. Disponível em: . Acesso em 23 abr. 2015.

PEDRO, Joana Maria. Traduzindo o debate: o uso da categoria gênero na pesquisa histórica. Revista História, São Paulo, v.24, N.1, P.77-98, 2005.

SHIFMAN, Limor. Memes In Digital Culture. Cambridge: MIT Press, 2013.

TOLEDO, Cecília. Mulheres: o gênero nos une, a classe nos divide. In. Marxismo Vivo, $n^{\circ}$ 2. São Paulo. Sundermann, 2001.

WARK, Jayne. Radical Gestures: feminism and performance art in North America, 1970 a 2000. Montreal: McGill, Queen ${ }^{e e}$ s University Press, 2006.

WOLF, Naomi. O Mito da Beleza. Como as Imagens de Beleza são usadas contra as Mulheres. Tradução de Waldéa Barcellos. Rio de Janeiro. Ed. Rocco, 1992.

WOLFF, Janet. Recuperando a corporalidade. Feminismo e política do corpo. In: MACEDO, Ana Gabriela; RAYNER, Francesca (Orgs.). Género, cultura visual e performance. Antologia Crítica. Minho: Edições Húmus, 2011. 